15 Valentine, R. C., and Wrigley, N. G., Nuture, 208,713 (1864),

${ }^{16}$ Markham, R., Frey, S., and Hills, G. J., Virolovy, 20, 88 (1962).

12 Dobb, M. G., J. Mol. Biol, (in the press).

${ }^{18}$ Lundgren, H. P., and Ward, W, H., A rch, Biochem. Biophys., Suppl. 1, 78

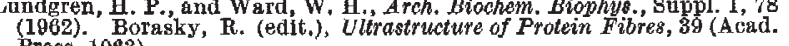
Press, 1963). 19 Fraser, R. D. B., MacRae, T. Y., Miller, A., and Suzuki, F., J. Mol. Biol., 9 ,
250 (1964).

\section{Ultrafine Structure of $a$-Keratin}

THE equivocal evidence for the structure of the $\alpha$-keratin microfibril as rovealed in transverse section has been discussed ${ }^{1,2}$, and it is clear that other methods of approach to the important problem of the arrangement of protein molecules within the microfibril must be used together with sectioning tochniques. Again, there is little experimontal evidence about the length of the individual protein molecules in the microfibrils and their possible mode of longitudinal polymerization. Thus, in this communication wo prosent a technique for disporsing the microfibrils, prior to negative staining, which is proving useful in the examination of lateral and longitudinal arrangement of protoin molecules in koratin.

Fractionation mothods applied to fibrous keratin give rise to two main fractions ${ }^{a}$. One fraction is rich in sulphur compared with the original fibre, has a molecular weight of 22,000 and exists in buffor solutions as a random coil ${ }^{4}$. The other fraction is low in sulphur compared with the original fibre, may have a molecular weight of 100,000 , and can be regenerated as oriented films which give an X-ray diffraction photograph largely of the $\alpha$ typo but with traces of tho cross and parallol $\beta$ configurations ${ }^{s}$. Harrap and Gillospie ${ }^{6}$ have examined extensively the fractionation of wool keratin after alkaline reduction and have shown that treatment by sodium thioglycollate at $4^{\circ} \mathrm{C}$ for $18 \mathrm{~h}$ at $p \mathrm{H} 10.5$ oxtracts a protein onriched in the high sulphur fraction and loaves a fibrous residue onriched in the low sulphur protein. This residue has boen shown to give a disoriented X-ray diffraction pattern of the $\alpha$ type? As high sulphur content proteins havo beon tentatively identified with the matrix which surrounds the microfibrils, it was thought that this type of extraction might give a relativoly eloan preparation of microfibrils which, because of the reduction of disulphide bonds, might be induced to break up into smallor units by the application of ultrasonic irradiation.

The technique finally adopted was to roduce Morino 64's wool, which had beon purified by washing with ether, alcohol, and distillod water, with $0.1 \mathrm{M}$ thioglycollic acid in $0.1 \mathrm{M}$ disodium hydrogen phosphate adjusted to $p \mathrm{H}$ 10.0 or 10.5 with sodium hydroxide, The fibrous residue was then transforred to an intracellular physiological buffer ${ }^{8}$ containing potassium, magnesium, chloride, and phosphate ions at $p \mathrm{H} 7 \cdot 0$, and irradiated with ultrasonics at $15 \mathrm{e} / \mathrm{s}$ and $20 \mathrm{~W} \mathrm{~cm} \mathrm{~cm}^{-2}$ for $5 \mathrm{~h}$. The tornporature in the water-cooled cell remained at $12^{\circ} \mathrm{C}$ throughout the irradiation. The dispersed material was centrifuged at $500 \mathrm{~g}$ for $5 \mathrm{~min}$, the supornatant liquid discarded, the sodiment washed with buffer and rocentrifugod and, finally, resuspended in 1 por cont sodium phosphotungstate at $p \mathrm{H} 5.6$ and irradinted with ultrasonics for a furthor period of about $1 \mathrm{~h}$. Drops of the dispersod material wore then placed on 'holey' carbon film on specimen supporting grids and examined in a Siemons Elmiskop $I$ electron mioroscope after desiccation.

It may be noted that, as in tho case of transverse sections', optimum contrast in tho specimen is found at $a$ slightly under-focusod setting of the objective lens with respect to true focus as defined by tho absonce of Fresnel diffraction at tho edge of a holo. Because of this tho structure of the carbon film is out of focus and tonds to distort the appearance of the specimon. Fig. 1 shows a typical area of tho preparation and it is evident that the microfibrils have boon dispersed into long filamonts or protofibrils; indeed there was no evidenco of intact miorofibrils remaining in tho preparation. Microdensito- metor traces with a long slit have been mado on the nogatively stained filaments and revoel widths botween $12 \AA$ and $40 \AA$; however, a width of approximately $20 \AA$ predominates. In the region indicatod by the arrows there are three filaments about $12 \AA, 18 \AA$ and $40 \AA$ in width, but their identities are not maintainod for any great length. In Fig. 1 and other micrographs, some of the $20 \AA$ wide filamonts appear to be composed of still smaller filaments twisted together, but it is not yet possible to say how many of these smaller filaments are present because of the background noise.

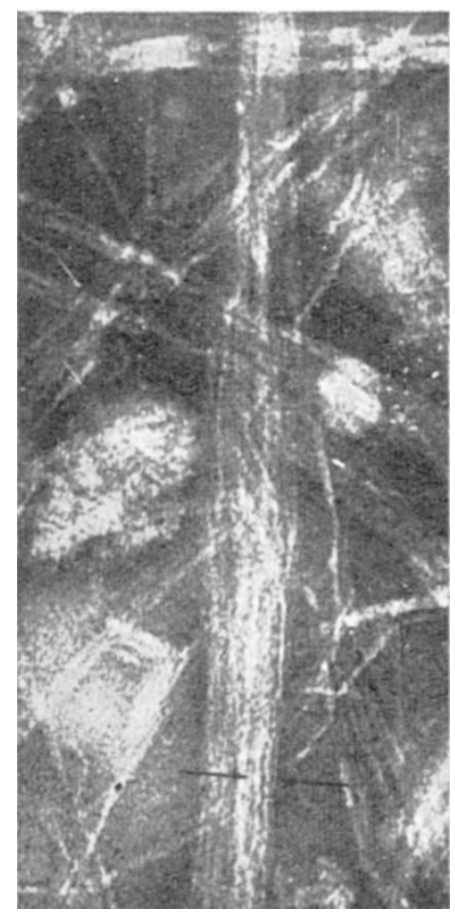

Fig. 1. Merino wool reduced, dispersed by ultrasonic irradiation, and stained with phosphotungstic acid $(\times \mathbf{2 7 5}, 000)$

It may be tentativoly suggestod that the smallost filamonts seen here aro single protein molecules, and that the predominant $20 \AA$ wide filaments aro two- or threestrand ropos. Novertholoss, other arrangements of the molecules cannot be excluded. From theso results it is difficult to say whether or not any ono arrangement is maintained for a great distance along the microfibril, and there is no indication of a unique structure for the microfibril. Further work is being carried out.

Finally, it should bo noted that, in an indopondent investigation, Dobb ${ }^{9}$ has dispersed the microfibrils using a different technique and again finds prodominant evidence of $20 \AA$ wide protofibrils.

Wo thank Dr. J, Sikorski for his advieo. This work was supported by the Wool Textile Resenrch Council.

$$
\begin{aligned}
& \text { D. J. Johnson } \\
& \text { P. T. SPEakman }
\end{aligned}
$$

Textile Physics and Textile Chemistry Laboratories, Department of 'Textile Industries, University of Leeds.

${ }^{1}$ Johnson, D. J., and Sikorski, J., Nature, 194, 81 (1962).

2 Johnson, D, J, , and Slkorski, J. (preceding communicalion).

8 Earland, C., and Wlseman, A., Diochim. Biophys. Acta, 36, 273 (1954).

- Gillespie, J. M., and Harrap, B. S., A ustral. J. Biol. Sci., 16, 252 (1963).

' Rogers, G. E., A nn. N.Y. A cad. Sci, 88, 408 (1050).

Harrap, B. S., and Gillespic, J. M., A ustral, J, Biol. Soi., 16, 542 (1963).

- Bailey, C. J., and Speakman, P. T. (in preparation).

${ }^{8}$ Lowry, O. M., Biol. Symp., 10, 283 (1943).

'Dobb, M. G., J. Mol. Biol., 10, 156 (1964). 